\title{
Pengaruh Kemiringan Lereng terhadap Kerusakan Tanah di Giritontro, Wonogiri
}

\author{
MUJIYO $^{1 *}$, WIDHI LARASATI ${ }^{2}$, HERY WIDIJANTO ${ }^{1}$, DAN AKTAVIA HERAWATI ${ }^{1}$ \\ ${ }^{1}$ Program Studi Ilmu Tanah, Fakultas Pertanian, Universitas Sebelas Maret, Surakarta \\ ${ }^{2}$ Program Studi Agroteknologi, Fakultas Pertanian, Universitas Sebelas Maret, Surakarta \\ ${ }^{*}$ E-mail: mujiyo@ staff.uns.ac.id
}

\begin{abstract}
The Effect of Slope Gradient of land on the Soil Damage in Giritontro, Wonogiri. Soil degradation is one of the problems in agriculture that affects the level of quality and carrying capacity of the soil for certain land uses. This study aims to analyse the status of soil degradation, the effect of slope, the determinant factor, and recommendation for land management.It was conducted in Giritontro District, Wonogiri Regencywith survey methods by field verification, taking soil samples and laboratoryanalysis based on Regulation of The Government of Indonesia Number 150 of 2000. Analysis unit is land map unit (LMU) which obtained from an overlay of mapssoil types, slope, rainfall, and land use. There were $12 \mathrm{LMU}$, and repeated 3 site samplings in each it. The result shows that the status of soil degradation was classified as slightly degraded (R.I) in all area research of 5.016.37 ha. The slope has a very significant effect on soil degradation. Slope 26$40 \%$ has significant highest score of soil degradration. Determinant factors were soil bulk density and porosity, therefore giving organic matter and optimizing tillage were recommended to improve land quality.
\end{abstract}

Keywords: soil degradation, slope, porosity, bulk density

\section{PENDAHULUAN}

Kerusakan tanah adalah salah satu masalah di bidang pertanian yang terjadi pada suatu wilayah yang mempengaruhi tingkat kualitas dan daya dukung tanah untuk penggunaan lahan tertentu.Kerusakan tanah merupakan penurunan kemampuan tanah dalam memproduksi biomassa yang dapat terjadi melalui kerusakan sifat fisika, kimia dan biologi tanah (Young et al. 2015). Adanya kerusakan lahan pertanian akibat dari budidaya yang kurang tepat atau karena faktor dari luar akan mengakibatkan penurunan kualitas tanah (Sukisno et al. 2011). Ajayi (2015) mengemukakan bahwa aktivitas manusia dapat menyebabkan penurunan kapasitas produktif tanah baik secara sementara maupun permanen. Selain itu, kerusakan tanah menyebabkan perubahan fungsi tanah sebagai media tumbuh tanaman (Sumarno et al., 2015).

Unsur pembentuk karakteristik suatu lahan terdiri dari jenis tanah, vegetasi, iklim dan 


\section{Mujiyo et al. Pengaruh Kemiringan Lereng terhadap Kerusakan Tanah di Giritontro...}

topografi. Topografi wilayah diantaranya kemiringan lereng yang merupakan faktor yang perlu diperhatikan mulai dari persiapan lahan, upaya penanaman, pengambilan hasil dan konservasi lahan. Lahan dengan tingkat kemiringan yang tinggi akan lebih mudah terganggu atau rusak. Lahan dengan kemiringan $>15 \%$ dan curah hujan tinggi dapat menyebabkan terjadinya tanah longsor (Andrian et al., 2014). Martono (2004) dan Andrian et al. (2014) menyatakan bahwa lereng yang semakin curam dan semakin panjang akan meningkatkan jumlah erosi. Lereng yang semakin curam akan mempercepat aliran permukaan sehingga erosi akan meningkat.

Kecamatan Giritontro merupakan salah satu kecamatan di Kabupaten Wonogiri didominasi pertanian lahan kering dengan beberapa jenis pengunaan lahan. Kecamatan Giritontro menurut BPS Kabupaten Wonogiri (2019) mempunyai luas wilayah $6.163,15$ hektar dengan penggunaan lahan berupa tegalan (4.425,23 ha), sawah (393,71 ha), bangunan dan pekarangan (892,30 ha), hutan negara $(373,00$ ha), padang rumput (1,28 ha) dan lain-lain $(77,63$ ha). Topografi perbukitan dengan kemiringan lereng beragam $0-40 \%$ dengan curah hujan 1.750-2.250 mm/tahun.

Berdasarkan kondisi tersebut perlu dilakukan analisis status kerusakan tanah, pengaruh ragam kemiringan lereng terhadap kerusakan tanah, apa saja karakteristik tanah yang menjadi penentu kerusakan tanah, dan rekomendasi pengelolaan lahan yang dapat dialkukan untuk mempebaiki kerusakan tanah.

\section{BAHAN DAN METODE}

Kecamatan Giritontro Kabupaten Wonogiri merupakan lokasi penelitian yang secara geografis berada pada titik koordinat 8001'50,6"-8009'25,7" LS dan 110051'19,7'$110^{0} 56^{\prime} 15,9$ ' BT dengan ketinggian 162-440 m dpl. Penelitian dengan metode survei yaitu dengan melakukan pengamatan dan pengambilan sampel tanah di lapangan serta dilanjutkan dengan analisis laboratorium. Satuan analisis adalah satuan peta lahan (SPL) berdasar pada hasil overlay peta tematik jenis tanah, kemiringan lereng, curah hujan dan penggunaan lahan. Peta jenis tanah dan curah hujan dari Pusat Penelitian Tanah dan Agroklimat, dan peta kemiringan lereng dan penggunaan lahan dari Badan Koordinasi Survei dan Pemetaan Nasional. SPL sejumlah 12 (Tabel 1) yang masing-masing diulang 3 kali sehingga terdapat 36 titik pengamatan dan pengambilan sampel (site sampling). Site sampling ditentukan secara sengaja (purposive sampling) dengan mempertimbangkan keterwakilan SPL dan keterjangkauan (Gambar 1). 
Agrotrop : Journal on Agriculture Science, 11 (2): 115 - 128 (2021)

Tabel 1. Satuan peta lahan

\begin{tabular}{cllll}
\hline \multirow{2}{*}{ SPL } & $\begin{array}{l}\text { Jenis } \\
\text { Tanah }\end{array}$ & $\begin{array}{l}\text { Kemiringan } \\
\text { Lereng }(\%)\end{array}$ & $\begin{array}{l}\text { Curah Hujan } \\
(\mathrm{mm} / \mathrm{tahun})\end{array}$ & $\begin{array}{l}\text { Penggunaan } \\
\text { Lahan }\end{array}$ \\
\hline 1 & Mollisols & $0-8$ & 1.750 & Sawah \\
2 & Mollisols & $9-15$ & 2.250 & Sawah \\
3 & Alfisols & $0-8$ & 1.750 & Sawah \\
4 & Inceptisols & $0-8$ & 1.750 & Sawah \\
5 & Mollisols & $0-8$ & 1.750 & Kebun \\
6 & Mollisols & $0-8$ & 2.250 & Kebun \\
7 & Mollisols & $9-15$ & 1.750 & Kebun \\
8 & Mollisols & $26-40$ & 1.750 & Kebun \\
9 & Mollisols & $0-8$ & 1.750 & Tegalan \\
10 & Mollisols & $0-8$ & 2.250 & Tegalan \\
11 & Mollisols & $9-15$ & 1.750 & Tegalan \\
12 & Mollisols & $9-15$ & 2.250 & Tegalan \\
\hline
\end{tabular}

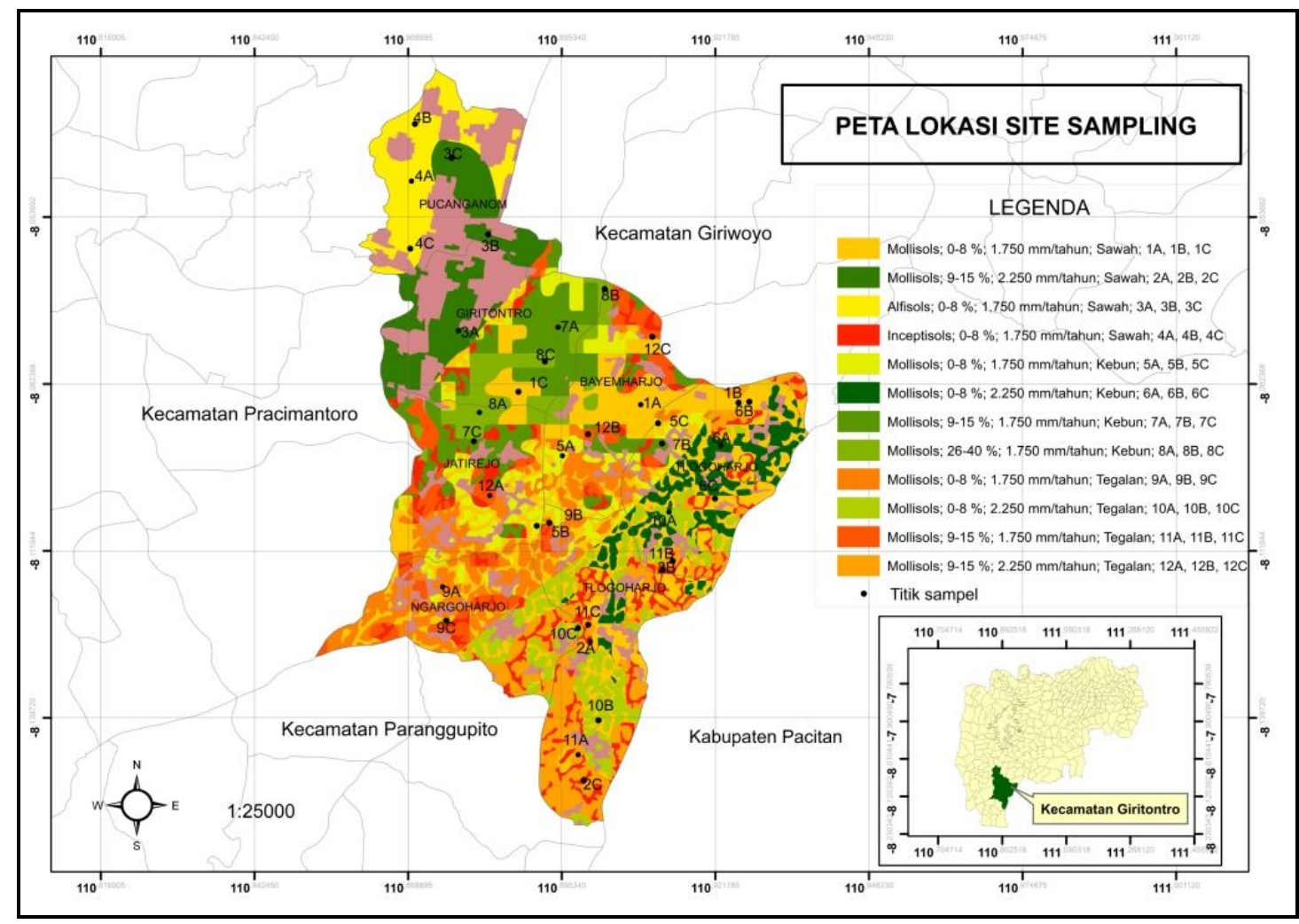

Gambar 1. Satuan peta lahan dan site sampling

Status kerusakan tanah ditentukan dengan perhitungan dari skoring parameter kerusakan tanah berdasar kriteria baku kerusakan tanah (Peraturan Pemerintah
Republik Indonesia Nomor 150 Tahun 2000) (Tabel 2). Parameter kerusakan tanah meliputi sifat fisika, kimia dan biologi tanah yaitu ketebalan solum, kebatuan permukaan, tekstur 
Mujiyo et al. Pengaruh Kemiringan Lereng terhadap Kerusakan Tanah di Giritontro...

tanah, berat volume tanah, porositas total tanah, derajat pelulusan air, $\mathrm{pH}$, daya hantar listrik (DHL), redoks dan jumlah mikroba. Sumarno et al. (2015) mengatakan bahwa setiap parameter pengamatan memiliki batas ambang kritis masing-masing.

Tabel 2. Parameter kriteria baku kerusakan

\begin{tabular}{cll} 
No. & \multicolumn{1}{c}{ Parameter } & \multicolumn{1}{c}{ Ambang Kritis } \\
\hline 1. & Ketebalan solum & $<20 \mathrm{~cm}$ \\
2. & Kebatuan permukaan & $>40 \%$ \\
3. & Komposisi fraksi & $<18 \% \mathrm{koloid} ;>80 \%$ pasir \\
4. & Berat isi & $>1,4 \mathrm{gr} / \mathrm{cm}^{3}$ \\
5. & Porositas total & $<30 \% ;>70 \%$ \\
6. & Derajat pelulusan air & $<0,7 \mathrm{~cm} / \mathrm{jam} ;>8,0 \mathrm{~cm} / \mathrm{jam}$ \\
7. & pH $\left(\mathrm{H}_{2} \mathrm{O}\right) 1: 2,5$ & $<4,5 ;>8,5$ \\
8. & DHL & $>4,0 \mathrm{mS} / \mathrm{cm}$ \\
9. & Redoks & $<200 \mathrm{mV}$ \\
10. & Jumlah mikroba & $<10^{2} \mathrm{cfu} / \mathrm{g}$ tanah \\
\hline
\end{tabular}

Sumber : Peraturan Pemerintah Indonesia Nomor 150 Tahun 2000

Metode pengukuran kerusakan tanah dengan matching atau pencocokan dan skoring dari setiap parameter kriteria baku kerusakan. Setiap parameter pada SPL dihitung frekuensi

Tabel 3. Skor kerusakan tanah berdasarkan frekuensi relatif setiap parameter

\begin{tabular}{ll}
\hline Frekuensi Relatif Tanah Rusak (\%) & Skor \\
\hline $0-10$ & 0 \\
$11-25$ & 1 \\
$26-50$ & 2 \\
$51-75$ & 3 \\
$76-100$ & 4 \\
\hline
\end{tabular}

Tabel 4. Status kerusakan tanah berdasarkan nilai akumulasi skor kerusakan tanah

\begin{tabular}{lll}
\hline Simbol & Status Kerusakan Tanah & Nilai Akumulasi Skor \\
\hline N & Tidak rusak & 0 \\
R.I & Rusak ringan & $1-14$ \\
R.II & Rusak sedang & $15-24$ \\
R.III & Rusak berat & $25-34$ \\
R.IV & Rusak sangat berat & $35-40$ \\
\hline
\end{tabular}

Analisis statistik dengan ANOVA untuk mengetahui pengaruh kemiringan lereng terhadap kerusakan tanah, apabila ada pengaruh relatifnya (Tabel 3). Status kerusakan tanah setiap SPL dihitung berdasar hasil penjumlahan frekuensi relatif (\%) (Tabel 4). nyata dilanjutkan dengan DMRT untuk mengetahui perbedaan antar kemiringan lereng. Uji korelasi untuk mengetahui hubungan antara 
Agrotrop : Journal on Agriculture Science, 11 (2): 115 - 128 (2021)

parameter kriteria baku kerusakan tanah dengan skor kerusakan tanah, yang kemudian sebagai dasar untuk memperoleh faktor penentu. Rekomendasi pengelolaan lahan didasarkan kepada upaya untuk memperbaiki faktor penentu.

\section{HASIL DAN PEMBAHASAN}

\section{Status kerusakan tanah}

Kecamatan Giritontro memiliki status kerusakan tanah ringan (R.I) pada seluruh SPL dengan faktor pembatas yang berbeda-beda. SE et al. (2017) mengemukakan tingkat kerusakan tanah di suatu wilayah berbeda-beda tergantung pada tingkat kestabilan atau ketahanan tanah terhadap degradasi tanah, karakteristik tanah, serta sifat iklim wilayah tersebut.Tabel 5 menunjukkan bahwa pada SPL 1, 4, 5, 6, 7, 9, 10 dan 12 mempunyai faktor pembatas berupa parameter yang rusak meliputi berat volume, porositas total dan derajat pelulusan air. Sementara itu parameter yang rusak pada SPL 2 meliputi porositas total dan derajat pelulusan air,dan pada SPL 3 meliputi berat volume dan porositas total. SPL 8 mempunyai parameter yang rusak paling banyak meliputi ketebalan solum, kebatuan permukaan, berat volume, porositas total dan derajat pelulusan air. SPL 11 mempunyai hanya satu parameter yang rusak yaitu porositas total.Skor tiap parameter yang mengalami kerusakan serta total skor kerusakan tiap SPL dapat dilihat padaTabel 6. SPL 11 mempunyai tingkat kerusakan paling rendah dengan total skor 2, sedangkan SPL 8 mempunyai tingkatkerusakan paling tinggi dengan total skor 13. SPL 8 terletak pada wilayah dengan tingkat kemiringan lereng tertinggi yaitu $26-40 \%$. Semakin tinggi lereng suatu wilayah maka akan semakin tinggi potensi terjadinya erosi tanah. Andrian et al. (2014) dan Kasmawati et al. (2016) menyampaikan semakin miring lereng pada tanah akan semakin besar pula kecepatan aliran air di permukaannya sehingga pengikisan terhadap bagian-bagian tanah semakin besar. Dela \& Mardiatno (2012) menyatakan bahwa kecepatan aliran akan meningkat sejalan dengan semakin besarnya nilai kemiringan lereng dan daya angkut partikel-partikel tanah yang telah hancur akan semakin tinggi sehingga proses erosi akan semakin besar. 
Mujiyo et al. Pengaruh Kemiringan Lereng terhadap Kerusakan Tanah di Giritontro...

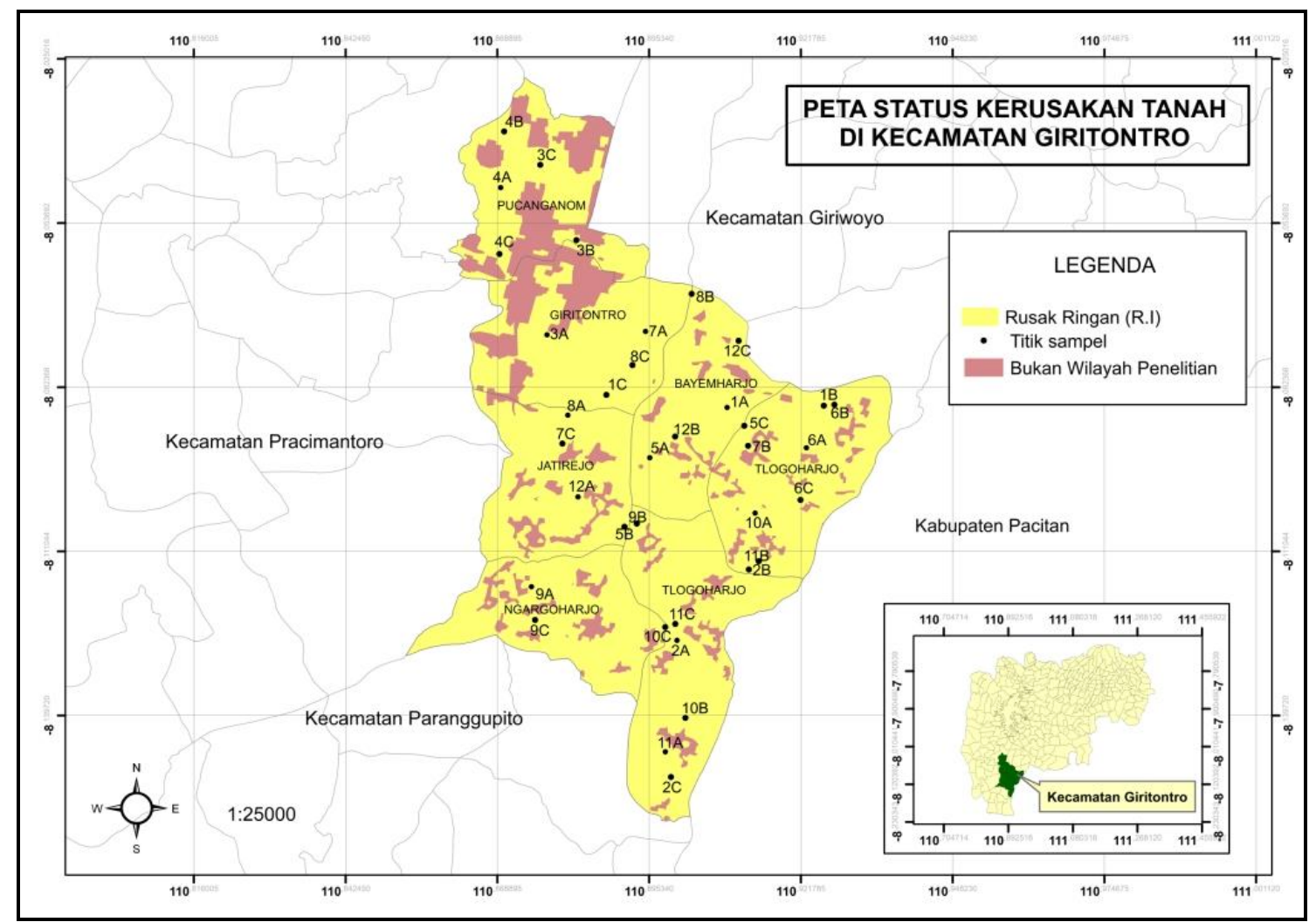

Gambar 2. Peta status kerusakan tanah di Kecamatan Giritontro 
Agrotrop : Journal on Agriculture Science, 11 (2): 115 - 128 (2021)

Tabel 5. Hasil matching parameter kriteria baku kerusakan tanah

\begin{tabular}{|c|c|c|c|c|c|c|c|c|c|c|c|c|}
\hline \multirow[b]{2}{*}{ SPL } & \multirow[b]{2}{*}{ Ulangan } & \multirow{2}{*}{$\begin{array}{l}\text { Ketebelan } \\
\text { Solum }(\mathbf{c m})\end{array}$} & \multirow{2}{*}{$\begin{array}{c}\text { Kebatuan } \\
\text { Permukaan } \\
(\%)\end{array}$} & \multicolumn{2}{|c|}{ Komposisi Fraksi } & \multirow{2}{*}{$\begin{array}{c}\text { Berat } \\
\text { Volume } \\
\left(\mathrm{gr} / \mathrm{cm}^{3}\right)\end{array}$} & \multirow{2}{*}{$\begin{array}{l}\text { Porositas } \\
\text { Total }(\%)\end{array}$} & \multirow{2}{*}{$\begin{array}{c}\text { Derajat } \\
\text { Pelulusan Air } \\
(\mathrm{cm} / \mathrm{jam})\end{array}$} & \multirow[b]{2}{*}{ pH } & \multirow{2}{*}{$\begin{array}{c}\mathrm{DHL}(\mathrm{mS} / \mathrm{c} \\
\mathbf{m})\end{array}$} & \multirow{2}{*}{$\begin{array}{l}\text { Redoks } \\
(\mathrm{mV})\end{array}$} & \multirow{2}{*}{$\begin{array}{c}\text { Jumlah } \\
\text { Mikroba(cfu/g } \\
\text { tanah) }\end{array}$} \\
\hline & & & & Pasir (\%) & Koloid (\%) & & & & & & & \\
\hline \multirow[t]{3}{*}{1} & 1 & $90 \mathrm{TR}$ & $2 \mathrm{TR}$ & $50 \mathrm{TR}$ & $50 \mathrm{TR}$ & $1,55 \mathrm{R}$ & $20,51 \mathrm{R}$ & $4,25 \mathrm{TR}$ & $6,87 \mathrm{TR}$ & $0,151 \mathrm{TR}$ & $336 \mathrm{TR}$ & $1,00 \times 10^{8} \mathrm{TR}$ \\
\hline & 2 & $25 \mathrm{TR}$ & $2 \mathrm{TR}$ & $45 \mathrm{TR}$ & $55 \mathrm{TR}$ & $2,64 \mathrm{R}$ & $17,35 \mathrm{R}$ & $13,27 \mathrm{R}$ & 6,63 TR & $0,112 \mathrm{TR}$ & $356 \mathrm{TR}$ & $1,11 \times 10^{8} \mathrm{TR}$ \\
\hline & 3 & $35 \mathrm{TR}$ & $2 \mathrm{TR}$ & $54 \mathrm{TR}$ & $46 \mathrm{TR}$ & $1,75 \mathrm{R}$ & $12,50 \mathrm{R}$ & $2,54 \mathrm{TR}$ & $7,10 \mathrm{TR}$ & $0,196 \mathrm{TR}$ & $316 \mathrm{TR}$ & $9,4 \times 10^{7} \mathrm{TR}$ \\
\hline \multirow[t]{3}{*}{2} & 1 & $38 \mathrm{TR}$ & $10 \mathrm{TR}$ & $21 \mathrm{TR}$ & $79 \mathrm{TR}$ & $1,92 \mathrm{R}$ & $17,24 \mathrm{R}$ & $7,65 \mathrm{TR}$ & $6,88 \mathrm{TR}$ & $0,096 \mathrm{TR}$ & $389 \mathrm{TR}$ & $2,7 \times 10^{7} \mathrm{TR}$ \\
\hline & 2 & $45 \mathrm{TR}$ & $3 \mathrm{TR}$ & $24 \mathrm{TR}$ & $76 \mathrm{TR}$ & $1,22 \mathrm{TR}$ & $44,29 \mathrm{TR}$ & $10,62 \mathrm{R}$ & $6,58 \mathrm{TR}$ & $0,104 \mathrm{TR}$ & $295 \mathrm{TR}$ & $4,0 \times 10^{6} \mathrm{TR}$ \\
\hline & 3 & $35 \mathrm{TR}$ & $3 \mathrm{TR}$ & $12 \mathrm{TR}$ & $88 \mathrm{TR}$ & $1,42 \mathrm{R}$ & $30,05 \mathrm{TR}$ & $6,37 \mathrm{TR}$ & $6,98 \mathrm{TR}$ & $0,064 \mathrm{TR}$ & $315 \mathrm{TR}$ & $5,3 \times 10^{7} \mathrm{TR}$ \\
\hline \multirow[t]{3}{*}{3} & 1 & $65 \mathrm{TR}$ & $0 \mathrm{TR}$ & $48 \mathrm{TR}$ & $52 \mathrm{TR}$ & $1,62 \mathrm{R}$ & $26,70 \mathrm{R}$ & $3,54 \mathrm{TR}$ & $6,86 \mathrm{TR}$ & $0,096 \mathrm{TR}$ & $389 \mathrm{TR}$ & $7,2 \times 10^{7} \mathrm{TR}$ \\
\hline & 2 & $52 \mathrm{TR}$ & $3 \mathrm{TR}$ & $34 \mathrm{TR}$ & $66 \mathrm{TR}$ & $2,07 \mathrm{R}$ & $8,00 \mathrm{R}$ & $2,90 \mathrm{TR}$ & 7,01 TR & $0,142 \mathrm{TR}$ & $386 \mathrm{TR}$ & $6,5 \times 10^{7} \mathrm{TR}$ \\
\hline & 3 & $70 \mathrm{TR}$ & $3 \mathrm{TR}$ & $60 \mathrm{TR}$ & $40 \mathrm{TR}$ & $1,69 \mathrm{R}$ & $21,40 \mathrm{R}$ & $3,98 \mathrm{TR}$ & $7,15 \mathrm{TR}$ & $0,188 \mathrm{TR}$ & $434 \mathrm{TR}$ & $7,8 \times 10^{7} \mathrm{TR}$ \\
\hline \multirow[t]{3}{*}{4} & 1 & $120 \mathrm{TR}$ & $0 \mathrm{TR}$ & $26 \mathrm{TR}$ & $74 \mathrm{TR}$ & $1,05 \mathrm{TR}$ & $53,74 \mathrm{TR}$ & $15,93 \mathrm{R}$ & $6,85 \mathrm{TR}$ & $0,130 \mathrm{TR}$ & $370 \mathrm{TR}$ & $6,3 \times 10^{7} \mathrm{TR}$ \\
\hline & 2 & $82 \mathrm{TR}$ & $3 \mathrm{TR}$ & $33 \mathrm{TR}$ & $67 \mathrm{TR}$ & $1,63 \mathrm{R}$ & $31,22 \mathrm{TR}$ & $7,96 \mathrm{TR}$ & $7,15 \mathrm{TR}$ & $0,204 \mathrm{TR}$ & $397 \mathrm{TR}$ & $1,11 \times 10^{8} \mathrm{TR}$ \\
\hline & 3 & $30 \mathrm{TR}$ & $3 \mathrm{TR}$ & $22 \mathrm{TR}$ & $78 \mathrm{TR}$ & $1,82 \mathrm{R}$ & $22,88 \mathrm{R}$ & $0,53 \mathrm{R}$ & 7,44 TR & $0,279 \mathrm{TR}$ & $396 \mathrm{TR}$ & $1,5 \times 10^{7} \mathrm{TR}$ \\
\hline \multirow[t]{3}{*}{5} & 1 & $33,5 \mathrm{TR}$ & $40 \mathrm{TR}$ & $43 \mathrm{TR}$ & $57 \mathrm{TR}$ & $1,55 \mathrm{R}$ & $29,55 \mathrm{R}$ & $0,43 \mathrm{R}$ & $6,95 \mathrm{TR}$ & $0,219 \mathrm{TR}$ & $306 \mathrm{TR}$ & $5,2 \times 10^{6} \mathrm{TR}$ \\
\hline & 2 & $20 \mathrm{TR}$ & $10 \mathrm{TR}$ & $52 \mathrm{TR}$ & $48 \mathrm{TR}$ & $1,38 \mathrm{TR}$ & $40,26 \mathrm{TR}$ & $0,92 \mathrm{TR}$ & 6,94 TR & $0,236 \mathrm{TR}$ & $289 \mathrm{TR}$ & $4,3 \times 10^{6} \mathrm{TR}$ \\
\hline & 3 & $50 \mathrm{TR}$ & $10 \mathrm{TR}$ & $31 \mathrm{TR}$ & $69 \mathrm{TR}$ & $1,38 \mathrm{TR}$ & $50,36 \mathrm{TR}$ & $1,64 \mathrm{TR}$ & $6,95 \mathrm{TR}$ & $0,201 \mathrm{TR}$ & $296 \mathrm{TR}$ & $4,7 \times 10^{6} \mathrm{TR}$ \\
\hline \multirow[t]{3}{*}{6} & 1 & $65 \mathrm{TR}$ & $5 \mathrm{TR}$ & $67 \mathrm{TR}$ & $33 \mathrm{TR}$ & $1,34 \mathrm{TR}$ & $37,67 \mathrm{TR}$ & $2,26 \mathrm{TR}$ & $6,71 \mathrm{TR}$ & $0,205 \mathrm{TR}$ & $287 \mathrm{TR}$ & $9,3 \times 10^{6} \mathrm{TR}$ \\
\hline & 2 & $40 \mathrm{TR}$ & $7 \mathrm{TR}$ & $80 \mathrm{TR}$ & $20 \mathrm{TR}$ & $1,49 \mathrm{R}$ & $27,32 \mathrm{R}$ & $0,53 \mathrm{R}$ & $6,80 \mathrm{TR}$ & $0,290 \mathrm{TR}$ & $289 \mathrm{TR}$ & $4,7 \times 10^{6} \mathrm{TR}$ \\
\hline & 3 & $40 \mathrm{TR}$ & $7 \mathrm{TR}$ & $52 \mathrm{TR}$ & $48 \mathrm{TR}$ & $1,78 \mathrm{R}$ & $18,35 \mathrm{R}$ & 2,09 TR & 6,61 TR & $0,120 \mathrm{TR}$ & $362 \mathrm{TR}$ & $3,1 \times 10^{6} \mathrm{TR}$ \\
\hline \multirow[t]{3}{*}{7} & 1 & $32 \mathrm{TR}$ & $30 \mathrm{TR}$ & $43 \mathrm{TR}$ & $57 \mathrm{TR}$ & $1,40 \mathrm{TR}$ & 27,84 R & $3,40 \mathrm{TR}$ & $6,95 \mathrm{TR}$ & $0,241 \mathrm{TR}$ & $298 \mathrm{TR}$ & $8,8 \times 10^{6} \mathrm{TR}$ \\
\hline & 2 & $34 \mathrm{TR}$ & $7 \mathrm{TR}$ & $11 \mathrm{TR}$ & $89 \mathrm{TR}$ & $1,78 \mathrm{R}$ & $35,97 \mathrm{TR}$ & $0,42 \mathrm{R}$ & $6,45 \mathrm{TR}$ & $0,126 \mathrm{TR}$ & $255 \mathrm{TR}$ & $1,9 \times 10^{6} \mathrm{TR}$ \\
\hline & 3 & $29 \mathrm{TR}$ & $25 \mathrm{TR}$ & $77 \mathrm{TR}$ & $23 \mathrm{TR}$ & $1,53 \mathrm{R}$ & 19,47 R & $0,13 \mathrm{R}$ & $6,20 \mathrm{TR}$ & 0,077 TR & $302 \mathrm{TR}$ & $1,58 \times 10^{7} \mathrm{TR}$ \\
\hline \multirow[t]{3}{*}{8} & 1 & $17 \mathrm{R}$ & $50 \mathrm{R}$ & $19 \mathrm{TR}$ & $81 \mathrm{TR}$ & $1,45 \mathrm{R}$ & $30,95 \mathrm{TR}$ & $0,21 \mathrm{R}$ & $6,95 \mathrm{TR}$ & $0,163 \mathrm{TR}$ & $429 \mathrm{TR}$ & $5,6 \times 10^{6} \mathrm{TR}$ \\
\hline & 2 & $38 \mathrm{TR}$ & $15 \mathrm{TR}$ & $23 \mathrm{TR}$ & $77 \mathrm{TR}$ & $1,99 \mathrm{R}$ & 7,01 R & $0,74 \mathrm{TR}$ & $6,80 \mathrm{TR}$ & 0,193 TR & $402 \mathrm{TR}$ & $3,2 \times 10^{6} \mathrm{TR}$ \\
\hline & 3 & $38 \mathrm{TR}$ & $15 \mathrm{TR}$ & $47 \mathrm{TR}$ & $53 \mathrm{TR}$ & $1,71 \mathrm{R}$ & 7,07 R & $0,75 \mathrm{TR}$ & $6,70 \mathrm{TR}$ & $0,132 \mathrm{TR}$ & $389 \mathrm{TR}$ & $3,6 \times 10^{6} \mathrm{TR}$ \\
\hline \multirow[t]{3}{*}{9} & 1 & $37 \mathrm{TR}$ & $3 \mathrm{TR}$ & $46 \mathrm{TR}$ & $54 \mathrm{TR}$ & $1,55 \mathrm{R}$ & $27,91 \mathrm{R}$ & $0,66 \mathrm{R}$ & $6,75 \mathrm{TR}$ & $0,179 \mathrm{TR}$ & $287 \mathrm{TR}$ & $3,1 \times 10^{6} \mathrm{TR}$ \\
\hline & 2 & $50 \mathrm{TR}$ & $3 \mathrm{TR}$ & $40 \mathrm{TR}$ & $60 \mathrm{TR}$ & $1,61 \mathrm{R}$ & $13,90 \mathrm{R}$ & $0,80 \mathrm{TR}$ & $6,95 \mathrm{TR}$ & $0,152 \mathrm{TR}$ & $273 \mathrm{TR}$ & $9,0 \times 10^{5} \mathrm{TR}$ \\
\hline & 3 & $45 \mathrm{TR}$ & $10 \mathrm{TR}$ & $50 \mathrm{TR}$ & $50 \mathrm{TR}$ & $2,73 \mathrm{R}$ & $30,87 \mathrm{TR}$ & $0,74 \mathrm{TR}$ & $6,41 \mathrm{TR}$ & $0,126 \mathrm{TR}$ & $316 \mathrm{TR}$ & $5,3 \times 10^{6} \mathrm{TR}$ \\
\hline \multirow[t]{3}{*}{10} & 1 & $55 \mathrm{TR}$ & $30 \mathrm{TR}$ & $43 \mathrm{TR}$ & $57 \mathrm{TR}$ & $0,91 \mathrm{TR}$ & $58,26 \mathrm{TR}$ & $1,38 \mathrm{TR}$ & 6,91 TR & $0,123 \mathrm{TR}$ & $316 \mathrm{TR}$ & $1,11 \times 10^{7} \mathrm{TR}$ \\
\hline & 2 & $50 \mathrm{TR}$ & $7 \mathrm{TR}$ & $49 \mathrm{TR}$ & $51 \mathrm{TR}$ & $1,72 \mathrm{R}$ & $23,21 \mathrm{R}$ & $1,38 \mathrm{TR}$ & 7,01 TR & $0,119 \mathrm{TR}$ & $287 \mathrm{TR}$ & $2,0 \times 10^{7} \mathrm{TR}$ \\
\hline & 3 & $30 \mathrm{TR}$ & $2 \mathrm{TR}$ & $32 \mathrm{TR}$ & $68 \mathrm{TR}$ & $1,56 \mathrm{R}$ & $26,42 \mathrm{R}$ & $0,40 \mathrm{R}$ & $6,45 \mathrm{TR}$ & $0,066 \mathrm{TR}$ & $273 \mathrm{TR}$ & $2,3 \times 10^{6} \mathrm{TR}$ \\
\hline \multirow[t]{3}{*}{11} & 1 & $30 \mathrm{TR}$ & $10 \mathrm{TR}$ & $26 \mathrm{TR}$ & $74 \mathrm{TR}$ & $0,69 \mathrm{TR}$ & $70,39 \mathrm{TR}$ & $0,80 \mathrm{TR}$ & $6,71 \mathrm{TR}$ & $0,155 \mathrm{TR}$ & $281 \mathrm{TR}$ & $2,16 \times 10^{7} \mathrm{TR}$ \\
\hline & 2 & $30 \mathrm{TR}$ & $30 \mathrm{TR}$ & $19 \mathrm{TR}$ & $81 \mathrm{TR}$ & $1,02 \mathrm{TR}$ & $52,78 \mathrm{TR}$ & $2,12 \mathrm{TR}$ & $6,79 \mathrm{TR}$ & $0,165 \mathrm{TR}$ & $320 \mathrm{TR}$ & $3,2 \times 10^{6} \mathrm{TR}$ \\
\hline & 3 & $45 \mathrm{TR}$ & $5 \mathrm{TR}$ & $29 \mathrm{TR}$ & $71 \mathrm{TR}$ & $1,24 \mathrm{TR}$ & $41,51 \mathrm{TR}$ & $1,46 \mathrm{TR}$ & $6,95 \mathrm{TR}$ & $0,160 \mathrm{TR}$ & $287 \mathrm{TR}$ & $4,0 \times 10^{7} \mathrm{TR}$ \\
\hline \multirow[t]{3}{*}{12} & 1 & $45 \mathrm{TR}$ & $10 \mathrm{TR}$ & $27 \mathrm{TR}$ & $73 \mathrm{TR}$ & $1,20 \mathrm{TR}$ & $45,45 \mathrm{TR}$ & $0,40 \mathrm{R}$ & $6,57 \mathrm{TR}$ & $0,082 \mathrm{TR}$ & $466 \mathrm{TR}$ & $9,6 \times 10^{6} \mathrm{TR}$ \\
\hline & 2 & $40 \mathrm{TR}$ & $15 \mathrm{TR}$ & $16 \mathrm{TR}$ & $84 \mathrm{TR}$ & $1,65 \mathrm{R}$ & $19,12 \mathrm{R}$ & $1,06 \mathrm{TR}$ & 7,14 TR & $0,251 \mathrm{TR}$ & $408 \mathrm{TR}$ & $5,3 \times 10^{6} \mathrm{TR}$ \\
\hline & 3 & $25 \mathrm{TR}$ & $5 \mathrm{TR}$ & $29 \mathrm{TR}$ & $71 \mathrm{TR}$ & $1,22 \mathrm{TR}$ & $41,35 \mathrm{TR}$ & $0,27 \mathrm{R}$ & $6,94 \mathrm{TR}$ & $0,241 \mathrm{TR}$ & $376 \mathrm{TR}$ & $1,81 \times 10^{7} \mathrm{TR}$ \\
\hline
\end{tabular}

Keterangan: $\mathrm{R}=$ Rusak; TR $=$ Tidak Rusak 
Mujiyo et al. Pengaruh Kemiringan Lereng terhadap Kerusakan Tanah di Giritontro...

Tabel 6. Hasil matching dan skoring parameter kerusakan tanah

\begin{tabular}{|c|c|c|c|c|c|c|c|c|c|c|c|c|c|c|c|}
\hline \multirow[b]{2}{*}{ SPL } & \multirow[b]{2}{*}{ Ulangan } & \multirow{2}{*}{$\begin{array}{c}\text { Ketebelan } \\
\text { Solum } \\
(\mathrm{cm})\end{array}$} & \multirow{2}{*}{$\begin{array}{c}\text { Kebatuan } \\
\text { Permukaan } \\
(\%)\end{array}$} & \multicolumn{2}{|c|}{ Komposisi Fraksi } & \multirow{2}{*}{$\begin{array}{c}\text { Berat } \\
\text { Volume } \\
\left(\mathrm{gr} / \mathrm{cm}^{3}\right)\end{array}$} & \multirow[b]{2}{*}{$\begin{array}{l}\text { Porositas } \\
\text { Total }(\%)\end{array}$} & \multirow{2}{*}{$\begin{array}{c}\text { Derajat } \\
\text { Pelulusan } \\
\text { Air }(\mathrm{cm} / \mathrm{jam})\end{array}$} & \multirow[b]{2}{*}{ pH } & \multirow[b]{2}{*}{$\begin{array}{c}\text { DHL } \\
(\mathbf{m S} / \mathbf{c m})\end{array}$} & \multirow[b]{2}{*}{$\begin{array}{c}\text { Redoks } \\
(\mathrm{mV})\end{array}$} & \multirow{2}{*}{$\begin{array}{c}\text { Jumlah } \\
\text { Mikroba } \\
\text { (cfu/g tanah) }\end{array}$} & \multirow[b]{2}{*}{$\begin{array}{l}\text { Total } \\
\text { Skor }\end{array}$} & \multirow[b]{2}{*}{ Status } & \multirow[b]{2}{*}{ Faktor Pembatas } \\
\hline & & & & $\begin{array}{l}\text { Pasir } \\
(\%)\end{array}$ & $\begin{array}{c}\text { Koloid } \\
(\%)\end{array}$ & & & & & & & & & & \\
\hline \multirow[t]{3}{*}{1} & 1 & 0 & 0 & 0 & 0 & 4 & 4 & 2 & 0 & 0 & 0 & 0 & 10 & \multirow{3}{*}{$\begin{array}{l}\text { Rusak } \\
\text { Ringan }\end{array}$} & \multirow{3}{*}{$\begin{array}{l}\text { BV, Porositas, Deraja } \\
\text { Pelulusan Air }\end{array}$} \\
\hline & 2 & 0 & 0 & 0 & 0 & 4 & 4 & 2 & 0 & 0 & 0 & 0 & 10 & & \\
\hline & 3 & 0 & 0 & 0 & 0 & 4 & 4 & 2 & 0 & 0 & 0 & 0 & 10 & & \\
\hline \multirow[t]{3}{*}{2} & 1 & 0 & 0 & 0 & 0 & 3 & 2 & 2 & 0 & 0 & 0 & 0 & 7 & \multirow{3}{*}{$\begin{array}{l}\text { Rusak } \\
\text { Ringan }\end{array}$} & \multirow{3}{*}{$\begin{array}{l}\text { BV, Porositas, Deraja } \\
\text { Pelulusan Air }\end{array}$} \\
\hline & 2 & 0 & 0 & 0 & 0 & 3 & 2 & 2 & 0 & 0 & 0 & 0 & 7 & & \\
\hline & 3 & 0 & 0 & 0 & 0 & 3 & 2 & 2 & 0 & 0 & 0 & 0 & 7 & & \\
\hline \multirow[t]{3}{*}{3} & 1 & 0 & 0 & 0 & 0 & 4 & 4 & 0 & 0 & 0 & 0 & 0 & 8 & & \\
\hline & 2 & 0 & 0 & 0 & 0 & 4 & 4 & 0 & 0 & 0 & 0 & 0 & 8 & Rusak & BV, Porositas \\
\hline & 3 & 0 & 0 & 0 & 0 & 4 & 4 & 0 & 0 & 0 & 0 & 0 & 8 & & \\
\hline 4 & 1 & 0 & 0 & 0 & 0 & 3 & 2 & 3 & 0 & 0 & 0 & 0 & 8 & & \\
\hline & 2 & 0 & 0 & 0 & 0 & 3 & 2 & 3 & 0 & 0 & 0 & 0 & 8 & Rusak & BV, Porositas, Deraja \\
\hline & 3 & 0 & 0 & 0 & 0 & 3 & 2 & 3 & 0 & 0 & 0 & 0 & 8 & & \\
\hline 5 & 1 & 0 & 0 & 0 & 0 & 2 & 2 & 2 & 0 & 0 & 0 & 0 & 6 & & \\
\hline & 2 & 0 & 0 & 0 & 0 & 2 & 2 & 2 & 0 & 0 & 0 & 0 & 6 & Rusak & BV, Porositas, Deraja \\
\hline & 3 & 0 & 0 & 0 & 0 & 2 & 2 & 2 & 0 & 0 & 0 & 0 & 6 & & \\
\hline 6 & 1 & 0 & 0 & 0 & 0 & 3 & 3 & 2 & 0 & 0 & 0 & 0 & 8 & & \\
\hline & 2 & 0 & 0 & 0 & 0 & 3 & 3 & 2 & 0 & 0 & 0 & 0 & 8 & Rusak & BV, Porositas, Deraja \\
\hline & 3 & 0 & 0 & 0 & 0 & 3 & 3 & 2 & 0 & 0 & 0 & 0 & 8 & Ringan & Pelulusan Air \\
\hline 7 & 1 & 0 & 0 & 0 & 0 & 3 & 3 & 3 & 0 & 0 & 0 & 0 & 9 & & \\
\hline & 2 & 0 & 0 & 0 & 0 & 3 & 3 & 3 & 0 & 0 & 0 & 0 & 9 & Rusak & BV, Porositas, Deraja \\
\hline & 3 & 0 & 0 & 0 & 0 & 3 & 3 & 3 & 0 & 0 & 0 & 0 & 9 & Ringan & Pelulusan Air \\
\hline 8 & 1 & 2 & 2 & 0 & 0 & 4 & 3 & 2 & 0 & 0 & 0 & 0 & 13 & & Ketebalan solum, \\
\hline & 2 & 2 & 2 & 0 & 0 & 4 & 3 & 2 & 0 & 0 & 0 & 0 & 13 & Rusak & Kebatuan permukaan, \\
\hline & 3 & 2 & 2 & 0 & 0 & 4 & 3 & 2 & 0 & 0 & 0 & 0 & 13 & Ringan & $\begin{array}{l}\text { BV, Porositas, Deraja } \\
\text { Pelulusan Air }\end{array}$ \\
\hline 9 & 1 & 0 & 0 & 0 & 0 & 4 & 4 & 2 & 0 & 0 & 0 & 0 & 10 & & \\
\hline & 2 & 0 & 0 & 0 & 0 & 4 & 4 & 2 & 0 & 0 & 0 & 0 & 10 & $\begin{array}{l}\text { Kusak } \\
\text { Pingan }\end{array}$ & BV, Porositas, Deraja \\
\hline & 3 & 0 & 0 & 0 & 0 & 4 & 4 & 2 & 0 & 0 & 0 & 0 & 10 & Ringan & Pelulusan Air \\
\hline 10 & 1 & 0 & 0 & 0 & 0 & 3 & 3 & 2 & 0 & 0 & 0 & 0 & 8 & & \\
\hline & 2 & 0 & 0 & 0 & 0 & 3 & 3 & 2 & 0 & 0 & 0 & 0 & 8 & Rusak & BV, Porositas, Deraja \\
\hline & 3 & 0 & 0 & 0 & 0 & 3 & 3 & 2 & 0 & 0 & 0 & 0 & 8 & Ringan & \\
\hline 11 & 1 & 0 & 0 & 0 & 0 & 0 & 2 & 0 & 0 & 0 & 0 & 0 & 2 & & \\
\hline & 2 & 0 & 0 & 0 & 0 & 0 & 2 & 0 & 0 & 0 & 0 & 0 & 2 & Rusak & Porositas \\
\hline & 3 & 0 & 0 & 0 & 0 & 0 & 2 & 0 & 0 & 0 & 0 & 0 & 2 & Ringan & \\
\hline 12 & 1 & 0 & 0 & 0 & 0 & 2 & 2 & 3 & 0 & 0 & 0 & 0 & 7 & & \\
\hline & 2 & 0 & 0 & 0 & 0 & 2 & 2 & 3 & 0 & 0 & 0 & 0 & 7 & Rusak & BV, Porositas, Deraja \\
\hline & 3 & 0 & 0 & 0 & 0 & 2 & 2 & 3 & 0 & 0 & 0 & 0 & 7 & Ringan & Pelulusan Air \\
\hline
\end{tabular}




\section{Pengaruh kemiringan lereng terhadap kerusakan tanah}

Hasil ANOVA menunjukkan bahwa kemiringan lereng berpengaruh sangat nyata terhadap kerusakan tanah $(F$-count $=16.346, P$ value $=0,000, \mathrm{~N}=36)$. Tabel 7 menunjukkan hasil DMRT bahwa kemiringan lereng 26-40\% mempunyai rata-rata skor kerusakan tanah secara nyata lebih tinggidari pada kemiringan lereng yang lain. Peristiwa pengikisan tanah dipengaruhi besar oleh kondisi kemiringan lereng, pada lereng curam kecepatan infiltrasi semakin berkurang yang menyebabkan volume limpasan permukaan meningkat dan mengikis tanah (Dewi et al., 2012). Hal tersebut sesuai dengan pernyataan Christanto et al. (2010) bahwa kemiringan lereng semakin datar maka limpasan permukaan akan semakin lambat. Arsyad Sinatala (2000) dan Retno Wahyu Murti (2019) menyatakan limpasan menyebabkan kandungan bahan organik yang tinggi akan terbawa dan terangkut ke dataran yang lebih rendah. Hal tersebut membuat lahan pada kemiringan lereng yang tinggi (curam) sangat beresiko terjadi kerusakan tanah.

Tabel 7. Pengaruh kemiringan lereng terhadap kerusakan tanah

\begin{tabular}{|c|c|}
\hline Kemiringan Lereng & Total Skor Kerusakan Tanah \\
\hline $9-15 \%$ & $6,25 \mathrm{~b}$ \\
\hline $0-8 \%$ & $8,29 \mathrm{~b}$ \\
\hline $26-40 \%$ & $13,00 \mathrm{a}$ \\
\hline
\end{tabular}

Kemiringan lereng demikian juga hilangnya lapisan tanah bagian atas akibat erosi berpengaruh nyata terhadap porositas total dapat mengurangi struktur butiran bahan tanah $(F$-count $=3,322 ; P$-Value $=0,048, \mathrm{~N}=$ organik, unsur hara tanaman dan 36),pada kemiringan $26-40 \%$ secara nyata lebih mikroorganisme yang sebelumnya melimpah rendah dari pada kemiringan 9-15\%. Semakin pada lapisan tersebut. Sedangkan, porositas tinggi kemiringan lereng semakin rendah total tanah dipengaruhi oleh kondisi bahan persentase ruang pori tanah sehingga organik dan mikrooganisme tanah yang semakintinggi tingkat kerusakan tanahnya. berperan dalam memperbaiki struktur tanah Suyanto \& Wawan (2017) menyatakan bahwa termasuk diantaranya ruang-ruang pori tanah kemiringan lereng yang besar dapat menghilangkan lapisan tanah bagian atas sehingga tanah semakin menipis. Tyas \& Hermawan (2010) berpendapat bahwa (Bintang et al., 2016).

Kemiringan lereng berpengaruh tidak nyata terhadap berat volume tanah $(F$-count. $=$ 2,772; $P$-Value $=0,077 ; \mathrm{N}=36$ ), namun terdapat 


\section{Mujiyo et al. Pengaruh Kemiringan Lereng terhadap Kerusakan Tanah di Giritontro...}

kecenderungan bahwa berat volume pada kemiringan lereng 26-40\% lebih tinggi dari pada lainnya. Yulnafatmawita et al. (2008) menyatakan bahwa bahan organik dapat mempengaruhi berat volume tanah, semakin tinggi bahan organik akan semakin rendah berat volume tanah. Saribun (2007) dalam penelitiannya menyatakan bahwa kemiringan lereng tidak berpengaruh secara signifikan terhadap berat volume tanah. Lahan hutan pinus terdapat vegetasi tutupan lahan yang dapat menentukan pengaruh kemiringan lereng terhadap berat volume. Hal tersebut dapat menjadi akibat dari pertumbuhan akar vegetasi, curah hujan atau lalu lintas normal (Casanova et al., 2016).Selain itu, berat volume tanah dipengaruhi oleh kedalaman solum tanah (Primadani, 2008), tekstur tanah dan bahan organik (Sutanto, 2005; Arisandi et al., 2015). Kepadatan berat volume bukan sifat intrinsik tanah akan tetapi dipengaruhi oleh sifat eksternal, perubahan yang terkait, berbagai faktor, dan proses yang terjadi pada alam serta antropogenik (Zeng et al., 2013; Casanova et al., 2016).

\section{Faktor penentu kerusakan tanah}

Kemiringan lereng berpengaruh sangat nyata terhadap kerusakan tanah (F-count= 16.346, $P$-value $=0,000, \mathrm{~N}=36)$, berpengaruh nyata terhadap porositas total tanah $(F$-count $=$ 3,322; $P$-Value $=0,048, \mathrm{~N}=36)$, dan ada kecenderungan berpengaruh juga terhadap berat volumeberat volume tanah $(F$-count $.=2,772$;
$P$-Value $=0,077 ; \mathrm{N}=36)$. Kerusakan tanah berkorelasi sangat nyata negatif dengan porositas total tanah $(\mathrm{r}=-0,648 ;$ P-Value $=$ 0,$000 ; \mathrm{N}=36$ ) dan sangat nyata positif dengan berat volume tanah $(\mathrm{r}=0,557 ; P$-Value $=0,000$; $\mathrm{N}=36$ ). Porositas total tanah berkorelasi sangat nyata negatif dengan berat volume tanah $(\mathrm{r}=$ 0,904; $P$-Value $=0,000 ; \mathrm{N}=36)$. Hasil ANOVA dan uji korelasi tersebut menunjukkan bahwa berat volume tanah dan porositas total tanah adalah sebagai faktor penentu kerusakan tanah.

Berat volume tanah dengan porositas total tanah saling berkaitan, tanah yang padat mempunyai berat volume tanah yang tinggi dan ruang pori yang rendah. Mujiyo et al. (2020) menyatakan berat volume tanah yang lebih tinggi berarti tanah lebih padat sehingga porositas tanah rendah. Wicaksono et al. (2015) mengemukakan porositas tanah akan meningkat dan berat volume tanah akan menurunpada agregat tanah utuh yang disebabkan kandungan bahan organik. Sutanto (2005) dan Firmansyah \& Sukwika (2020) menyebutkan bahwa berat volume tanah mempengaruhi kadar air di dalam tanah. Tanah yang mempunyai berat volume $>1,43 \mathrm{~g} / \mathrm{cm}^{3}$ dan kemudian mengalami pemadatan tanah akan mempersulit tanah menjadi gembur yang dapat berakibat pada kemampuan akar tanaman untuk mencapai air dalam tanah. Sukisno et al. (2011) menjelaskan mengenai porositas total yang semakin besar maka semakin besar ruang pori dan akan berpengaruh terhadap laju air yang dapat lewat di dalam tanah. Selain itu, berat volume 
berbanding lurus dengan tingkat kekasaran partikel tanah, semakin kasar partikel tanah akan semakin besar berat volume dan juga terkait erat dengan tingkat kepadatan tanah dan kemampuan akar tanaman untuk menembus air (Budiarti et al., 2017).

\section{Rekomendasi pengelolaan lahan}

Rekomendasi pengelolaan lahan didasarkan kepada upaya untuk memperbaiki faktor penentu berat volume tanah dan porositas total tanah. Upaya perbaikan yang dapat dilakukan dengan melakukan penambahan bahan organik dan pengolahan tanah yang baik. Murphy (2015) menyatakan pupuk organik dapat memperbaiki sifat fisik tanah pada kedalaman 10-20 cm. Bahan organik dapat memperbaiki sifat fisik tanah seperti meningkatkan stabilitas agregat, meningkatkan porositas dan permeabilitas tanah. Bahan organik mempunyaiperanan penting dalam meningkatkan dan mempertahankan kesuburan kimia, fisika, dan fisiko-kimia serta biologi tanah (Muzaiyanah \& Subandi, 2016). Surya \& Hasibuan (2015) menyampaikan bahwa bahan organik mampu memperbaiki sifat fisik, kimia dan biologi tanah, dan secara fisik memperbaiki struktur tanah, menentukan tingkat perkembangan struktur tanah dan berperan pada pembentukan agregat tanah. Intara et al. (2011) menambahkan bahwa bahan organik memperbaiki keadaan struktur, aerasi, kapasitas menahan air tanah, mempengaruhi keadaan temperatur tanah dan menyediakan suatu zat hasil perombakan yang dapat membantu pertumbuhan tanaman. Selain itu, bahan organik membantu dalam konservasi nutrisi tanah dengan mencegah erosi dan peluruhan nutrisi dan permukaan tanah (Widiatiningsih et al., 2018).

Upaya lainnya yang dapat dilakukan yaitu pengolahan tanah yang baik dan benar. Sukisno et al. (2011) menyatakan bahwa penanganan untuk tanah dengan porositas kecil perlu dengan pengolahan tanah yang baik dan tepat. Chandra et al. (2018) menambahkan olah tanah minimum adalah salah satu cara pengelolaan tanah dengan melakukan pengolahan tanah seminimal mungkin tetapi masih memberikan kondisi yang menguntungkan bagi pertumbuhan tanaman. Pengolahan tanah secara minimum dilakukan pada lahan dengan kemiringan yang curam. Pengolahan tanah dan penanaman berdasar garis kontur dapat menurunkan erosi hingga 5\% dibandingkan dengan pengolahan tanah dan penanaman berdasar lereng (Manansal et al., 2006). Tanah yang diolah hanya pada bagian penanaman tanaman sedangkan areal lainnya tidak dilakukan pengolahan. Wahyuningtyas (2010) menyatakan bahwa olah tanah minimum termasuk dalam salah satu konservasi tanah dan air. Hal tersebut dikarenakan olah tanah minimal merupakan teknik pengolahan tanah yang mengupayakan seminimal mungkin kehilangan tanah akibat erosi pada lahan miring. 
Mujiyo et al. Pengaruh Kemiringan Lereng terhadap Kerusakan Tanah di Giritontro...

\section{SIMPULAN}

Status kerusakan tanah di seluruh areal penelitian di Kecamatan Giritontro Kabupaten Wonogiri tergolong rusak ringan dengan kisaran skor 2-13. Kemiringan lereng berpengaruh sangat nyata terhadap kerusakan tanah, pada lahan dengan kemiringan lereng 26$40 \%$ mempunyai skor kerusakan tanah secara nyata lebih tinggi dari pada $0-8 \%$ dan $9-15 \%$. Berat volume dan porositas tanahmerupakan faktor penentu kerusakan tanah, pada lahan yang skor kerusakan tanahnya tinggi mempunyai berat volume tinggi dan porositas total rendah. Rekomendasi pengelolaan lahan didasarkan kepada upaya untuk memperbaiki faktor penentu tersebut, oleh karena itu pemberian bahan organik dan optimalisasi pengolahan tanah disarankan untuk meningkatkan kualitas lahan dan mencegah kerusakan tanah lebih lanjut.

\section{UCAPAN TERIMA KASIH}

Penelitian ini didanai oleh Universitas Sebelas Maret Surakarta melalui hibah PNBP UNS. Kami mengucapkan terimakasih kepada Tiara, Norri, Fajar, Restu dan Yosua atas bantuannya dalam pelaksanaan survei dan analisis di laboratorium, dan kepada Novi atas bantuannya dalam penyusunan artikel.

\section{DAFTAR PUSTAKA}

Ajayi, A. S. (2015). Land degradation and the sustainability of agricultural production in Nigeria: A review. Journal of Soil Science and Environmental Management,
$6(9)$,

234-240.

https://doi.org/10.5897/JSSEM15.0507

Andrian, Supriadi, \& Marpaung, P. (2014). Pengaruh Ketinggian Tempat dan Kemiringan Lereng terhadap Produksi Karet (Hevea brasiliensis Muell. Arg.) di Kebun Hapesong PTPN III Tapanuli Selatan. E-Journal Agroekoteknologi, 2(3), 981-989.

Arisandi, G., Arifandi, J. A., \& Sudibya, J. (2015). Studi faktor penyebab kerusakan tanah di Daerah Aliran Sungai (DAS) Bomo Kabupaten Banyuwangi. Berkala Ilmiah Pertanian, 1-6.

Arsyad Sinatala. (2000). Konservasi Tanah \& Air. IPB. https://repository.ipb.ac.id/handle/123456 789/42667? show=full

Bintang, R., Suyarto, R., \& Kesumadewi, A. A. I. (2016). Kajian Status Kerusakan Tanah pada Lahan Pertanian di Kecamatan Denpasar. E Journal Agroteknologi Tropika, 5(1), 1-10.

BPS Kabupaten Wonogiri. (2019). Giritontro dalam angka (pp. 1-39). BPS Kabupaten Wonogiri. https://doi.org/1102001.3312030

Budiarti, Gravitiani, W., Evi, \& Mujiyo. (2017). Upaya Mitigasi Banjir di Sub DAS Samin Melalui Pengembangan Masyarakat Tangguh Bencana. Jurnal Teknologi Lingkungan, 18(2), 241. https://doi.org/10.29122/jtl.v18i2.962

Casanova, M., Tapia, E., Seguel, O., \& Salazar, O. (2016). Direct measurement and prediction of bulk density on alluvial soils of central Chile. Chilean Journal of Agricultural Research, 76(1), 105-113. https://doi.org/10.4067/S071858392016000100015

Chandra, D., Banuwa, I. S., \& Afrianti, N. A. (2018). PENGARUH SISTEM OLAH TANAH DAN PEMBERIAN HERBISIDA TERHADAP KEHILANGAN UNSUR HARA DAN BAHAN ORGANIK AKIBAT EROSI PADA PERTANAMAN JAGUNG MUSIM TANAM KETIGA DI LABORATORIUM LAPANG TERPADU 
LAMPUNG. J. Agrotek Tropika., 6(1), 56-65.

Christanto, R. E., Suryono, Mujiyo, \& Winarno, J. (2010). Pemetaan Tingkat Bahaya Erosi Lahan Kering di Kecamatan Jatipuro Kabupaten Karanganyar dengan Sistem Informasi Geografi (SIG). Sains Tanah-J Lmu Tanah Dan Agroklimatologi, $\quad 7(2), \quad$ 117-121. https://123dok.com/document/zpd40nrzchristanto-fakultas-pertanian-universitassurakarta-pertanian-universitassurakarta.html

Dela Risnain Tarigan, \& Mardiatno, D. (2012). Pengaruh Erosivitas dan Topografi Terhadap Kehilangan Tanah pada Erosi Alur di Daerah Aliran Sungai Secang Desa Hargotirto Kecamatan Kokap Kabupaten Kulonprogo. Tarigan, 1(3), 411-420.

http://lib.geo.ugm.ac.id/ojs/index.php/jbi/ article/view/109

DEWI, I., TRIGUNASIH, N., \& KUSMAWATI, T. (2012). Prediksi Erosi Dan Perencanaan Konservasi Tanah Dan Air Pada Daerah Aliran Sungai Saba. EJurnal Agroekoteknologi Tropika (Journal of Tropical Agroecotechnology), 1(1), 12-23.

Firmansyah, I., \& Sukwika, T. (2020). Penilaian Kondisi degradasi tanah di SPK Sawangan Kota Depok. Jurnal Tanah Dan Sumberdaya Lahan, 7 (1)(January), 45-57.

https://doi.org/10.21776/ub.jtsl.2020.007. 1.7

Intara, Y. I., Sapei, A., Erizal, Sembiring, N., \& Djoefrie, M. H. B. (2011). Pengaruh pemberian bahan organik pada tanah liat dan lempung berliat terhadap kemampuan mengikat air. Jurnal Ilmu Pertanian Indonesia, 16 (2), 130-135.

Kasmawati, Hasanah, U., \& Rahman, A. (2016). Prediksi Erosi pada Beberapa Penggunaan Lahan di Desa Labuan Toposo Kecamatan Labuan Kabupaten Donggala. E-J. Agrotekbis, 4(6), 659666.

Manansal, E., J.Lengkong, \& J.Supit. (2006). Aspek pengolahan tanah dalam konsevasi tanah dan air. Soil Environment Ilmu \& Teknologi, 4(April).

Martono. (2004). Pengaruh Intensitas Hujan dan Kemiringan Lereng Terhadap Laju Kehilangan Tanah pada Tanah Regosol Kelabu [Diponegoro University]. http://core.ac.uk/download/files/379/117 13338.pdf

Mujiyo, Sumarno, Sudadi, \& Retno Wisnu Murti. (2020). Asessment of soil degradation in Pitu District, Ngawi Regency. $\quad 7(2), \quad 2049-2057$. https://doi.org/10.15243/jdmlm.

Murphy, B. . (2015). Impact of soil organic matter on soil properties - a review with emphasis on Australian soils. Soil Research, 53(6), 605-635.

Muzaiyanah, S., \& Subandi. (2016). Peranan bahan organik dalam peningkatan produksi kedelai dan ubi kayu pada lahan kering masam (pp. 149-158). Balai Penelitian Kacang-kacangan dan Umbiumbian.

Peraturan Pemerintah Republik Indonesia Nomor 150 Tahun 2000. (2000). Pengendalian Kerusakan Tanah Untuk Produksi Biomassa. Pemerintah RI.

Primadani, P. (2008). Pemetaan kualitas tanah pada beberapa penggunaan lahan di Kecamatan Jatipuro Kabupaten Karanganyar. Universiitas Sebelas Maret.

Retno Wahyu Murti. (2019). Kajian status kerusakan tanah pada lahan kebun dan tegalan untuk produksi biomassa di Kecamatan Pitu Kabupaten Ngawi. Universitas Sebelas Maret.

Saribun, D. S. (2007). Pengaruh Jenis Penggunaan Lahan dan Kelas Kemiringan Lereng Terhadap Bobot Isi, Pororsitas Total, dan Kadar Air Tanah pada Sub-DAS Cikapundung Hulu. In Pustaka Unpad. Universitas Padjajaran.

SE, O., GU, C., Peth, S., \& Ouyang, Y. (2017). Soil organic matter as sole indicator of soil degradation. Environ Monit Asses, 189 (176), 1-19.

Sukisno, Hindarto, K. S., Hasanudin, \& Wicaksono, A. H. (2011). Pemetaan potensi dan status kerusakan tanah untuk 
Mujiyo et al. Pengaruh Kemiringan Lereng terhadap Kerusakan Tanah di Giritontro...

mendukung produktivitas biomassa di Kabupaten Lebong. Prosiding Seminar Nasional Budidaya Pertanian Pengendalian Alih Fungsi Lahan Pertanian, 140-157.

Sumarno, S., Hartati, S., \& Hapsari, R. C. (2015). Pemetaan status kerusakan tanah di Lahan Pertanian di Kecamatan Cepogo Kabupaten Boyolali. Agrosains: Jurnal Penelitian Agronomi, $17(1), 21$. https://doi.org/10.20961/agsjpa.v17i1.18 662

Surya, A., \& Hasibuan, Z. (2015). Pemanfaatan bahan organik dalam perbaikan beberapa sifat tanah pasir Pantai Selatan Kulon Progo. Journal of Agro Science, 3(1), 3140.

https://doi.org/10.18196/pt.2015.037.3140

Sutanto. (2005). Dasar-dasar ilmu tanah: konsep dan kenyataan. Kanisius.

Suyanto, \& Wawan. (2017). Pengaruh Kemiringan Lahan dan Mucuna bracteata terhadap Aliran permukaan dan Erosi di PT Perkebunan Nusantara V Kebun Lubuk Dalam. Jom Faperta, 4(1), 1-15.

Tyas, D., \& Hermawan, B. (2010). Hubungan antara Beberapa Karakteristik Fisik Lahan dan Produksi Kelapa Sawit Relations between Physical Characteristics of Land and Palm Oil Production. Akta Agrosia, 13(1), 35-39. http://repository.unib.ac.id/76/1/Akta 13(1)_35-39.pdf

Wahyuningtyas, R. S. (2010). Melestarikan lahan dengan olah tanah konservasi. Galam, 4(2), 81-96.

Wicaksono, T., Sagiman, S., \& Umran, I. (2015). Kajian aktivitas mikroorganisme tanah pada beberapa cara penggunaan lahan di Desa Pal Ix Kecamatan Sungai Kakap Kabupaten Kubu Raya (pp. 1-14). Fakultas Pertanian Universitas Tanjungpura.
Widiatiningsih, A., Mujiyo, \& Suntoro. (2018). Study of Soil Degradation Status at Jatipurno District, Keduang SubWatershed, Wonogiri Regency, Central Java. Journal of Soil Science and Agroclimatology, 15(1), 1-14. https://doi.org/10.15608/stjssa.v15i1.862

Young, R., Orsini, S., \& Fitzpatrick, I. (2015). Soil degradation: a major threat to humanity (pp. 1-15). Sustainable Food Trust. http://sustainablefoodtrust.org

Yulnafatmawita, Adrinal, \& Isminingsih, S. (2008). Kajian fisika tanah pada pertumbuhan tanaman manggis (Garcinia mangostana L.) di Kabupaten Lima Puluh Kota. Jurnal Solum, 2, 78-87. https://doi.org/10.1017/CBO9781107415 324.004

Zeng, C., Wang, Q., Zhang, F., \& Zhang, J. (2013). Temporal changes in soil hydraulic conductivity with different soil types and irrigation methods. Geoderma, 193-194, 290-299. https://www.researchgate.net/publication/ 256716448_Temporal_changes_in_soil_ hydraulic_conductivity_with_different_s oil_types_and_irrigation_methods 